\title{
Testicular Cancer Pathologic Primary Tumor TNM Finding v8
}

National Cancer Institute

\section{Source}

National Cancer Institute. Testicular Cancer Pathologic Primary Tumor TNM Finding v8. NCl Thesaurus. Code C140209.

A pathologic finding about one or more characteristics of testicular cancer, following the rules of the TNM AJCC V8 classification system as they pertain to staging of the primary tumor. 